\title{
HABEAS CORPUS IN EXTRADITION PROCEEDINGS
}

\section{JAMES E. CARTY*}

The basic provision underlying extradition is found in Article IV, § 2, cl. 2 of the Federal Constitution which provides, "A person charged in any State with treason, felony, or other crime, who shall flee from justice, and be found in another State, shall, on the demand of the executive Authority of the State from which he fled, be delivered up, to the State having Jurisdiction of the Crime." Obviously the provision is not self-executory, and the United States Supreme Court in Kentucky v. Dennison ${ }^{1}$ held that if the governor of the asylum state has a disinclination toward carrying out the obligation placed on him by the Constitution, there is no method by which he may be compelled to do so. But the case is exceptional where the governor of an asylum state declines to grant the request for extradition. State procedure pertaining to extradition is largely governed by the Uniform Criminal Extradition Act which is in force in thirty-five states. Typical extradition procedure may best be summarized by a short resumé of the Act.

Application for issuance of a requisition for extradition is presented to the governor of the demanding state by the prosecuting attorney who, in the application, states the name of the one charged with the crime, the crime charged, the circumstances of its commission, and the state in which the accused is believed to be. Similar provision is made for the application for a requisition to extradite an escapee from a penal or other such institution. The Act also provides that the application be verifled by affidavit and that certain papers such as certified copies of the indictment

\footnotetext{
* 2nd year law sudent, Duke University; A.B. Washington State College 1949.

124 How. (U.S.) 66 (1860). See Application of Middlebrooks, 88 F. Supp. 943 (S.D. Cal. 1950). The Uniform Criminal Extradition Act, $\$ 2$ makes it the duty of the governor of the asylum state to have arrested and delivered up to the executive authority of the demanding state, fugitives from the latter's justice.
} 
be attached thereto. ${ }^{2}$ But a warrant for the arrest of the accused may be issued on the oath of a credible person in the asylum state that the accused is a proper subject for extradition within the terms of the Act. ${ }^{3}$

The demand for extradition must be in writing alleging that the accused was present in the demanding state at the time of the commission of the alleged crime ${ }^{4}$ and that he thereafter fled the state. 5 The demand must be accompanied by a copy of an indictment or information supported by affidavit, or by a copy of an affidavit made before a magistrate together with a copy of any warrant issued thereon, or by a copy of a judgment of conviction or sentence imposed in execution thereof with a statement by the executive authority of the demanding state that the accused has escaped or broken the terms of bail, probation, or parole. The accused must be "substantially charged" with commission of a crime under the laws of the demanding state. And the indictment or other paper accompanying the demand must be authenticated by the executive authority of the demanding state. ${ }^{6}$

The governor of the asylum state may then cause an investigation to be made of the demand and the situation and circumstances of the one sought, and of whether he should be surrendered. ${ }^{7}$ If the governor decides to comply with the demand, he is to sign a warrant of arrest which must substantially set forth the facts necessary to the validity of its issuance. ${ }^{8}$ The guilt or innocence of the accused may not be inquired into by the governor or in

2 Uniforar Crminat Extradimion ACT, §23.

3 Sec. 13.

- Sec. 3.

- However, the governor of the asylum state may surrender one who was not in the demanding state at the time of the commission of the alleged crime, and thus not a fugitive from justice, if the accused has committed an act in the asylum or another state which results in the commission of a crime in the demanding state. Sec. 6 . This covers the unusual type of case where for instance a person standing in North Carolina shoots and kills a person standing in South Carolina.

- Sec. 3.

7 Sec. 4.

Sec. 7 . 
legal proceedings after a demand for extradition, in proper form, has been received by the governor, except as the question may be involved in identifying the one held as the person charged with the crime. ${ }^{9}$

The accused is not to be delivered over to the agent of the demanding state until he is taken before a judge of a court of record who is to inform the accused of the extradition request and that he has a right to counsel. If the accused or his counsel desire to test the legality of the arrest, a reasonable time is to be allowed for application for a writ of habeas corpus.10

It is made a misdemeanor for an officer to deliver the accused to the agent of the demanding state in willful disobedience of these provisions. ${ }^{11}$ While the offending officer may be penalized, the accused is deprived of the right to test the illegality of the detention in the asylum state. Perhaps federal legislation could be passed to alleviate this problem.

In addition to the statutory rules, there are a number of judicial principles which one finds the courts, federal and state, enunciating with a fair degree of regularity though with slightly different word arrangements. Aside from the Uniform Act, the principal rules in habeas corpus proceedings when the writ is sought to test the legality of the detention and prospective extradition are that the court in the asylum state or the federal court to which application for the writ is made may only determine whether: a crime

- Sec. 20.

10 Sec. 10.

1 Sec. 11. In addition to the above provisions, the accused may waive extradition proceedings by a written waiver after being advised by a judge of his rights in the matter. Sec. 25-A. But nothing in the Act is to be deemed a waiver of the power of the asyium state to try the accused or to regain custody of him for trial for offenses committed therein. Sec. 25-B. Once the accused has been returned to the demanding state, he may be tried for crimes other than those specifled in the request for extradition. Sec. 26. And one imprisoned or held under pending criminal proceedings in one state may, by agreement between the executive authority of one state and that of another, be taken to the latter state for trial, and at the conclusion of the proceedings or of the sentence therein, be returned to the former state for the completion of its judicial or penal action against him. Sec. 5 . 
was charged against the petitioner in the demanding state; $;^{12}$ the petitioner was in the demanding state at the time of the commission of the alleged crime $;^{13}$ he is a fugitive from justice $;^{14}$ or he is held in violation of the Constitution or laws of the United States. ${ }^{15}$ As under the Uniform Act, habeas corpus is not the proper procedure to test an alibi or the guilt or innocence of the accused $;^{16}$ the sufficiency of the indictment or complaint as a matter of technical pleading is not inquired into on habeas corpus ;17 the motives and purposes of the extradition proceedings cannot

\footnotetext{
12 Johnson v. Matthews, 182 F. 2d 677 (D.C. Cir. 1950), cert. den. 340 U.S. (adv. sht.) 828 (1950); Pierce v. Creecy, 210 U.S. 128 (1907); Biddinger v. Commissioner, 245 U.S. 128 (1917); Ex parte Spears, 88 Cal. 640, 26 P. 608 (1891); In re Waterman, 29 Nev. 288, 89 P. 291 (1907); Powell v. Meyer, 23 N.J. Misc. 222, 43 A.2d 175 (1945); Hyatt v. New York, 188 U.S. 691 (1903) ; Higley v. Millspaw, 281 N.Y. 441, 24 N.E.2d 117 (1939); Ex parte Lewis, 34 Nev. 28, 115 P. 729 (1911); Sherman v. Barr, 131 Misc. 915, 229 N.Y.S. 268 (1928); In re Ryan, 15 Misc. 303,36 N.Y.S. 888 (1895).

13 Johnson v. Matthews, supra note 12; Munsey v. Ciough, 196 U.S. 364 (1905) ; Hyatt $\nabla$. New York, supra note 12; Biddinger $\nabla$. Commissioner, supra note 12; Ex parte Shoemaker, 25 Cal. App. 551, 144 P. 985 (1914); Powell v. Meyer, supra note 12; Higley v. Millspaw, supra note 12; In re Ryan, supra note 12, People $\nabla$. O'Brien, 197 Misc. 1019, 96 N.Y.S.2d 401 (1950). Apparently the O'Brien case means that the requirement is no longer necessary in New York. Ex parte Brewer, 61 Cal.App.2d 388, 143 P.2d 33 (1943).

16 Hyatt $\nabla$. New York, supra note 12; Roherts v. Reilly, 116 U.S. 80 (1885); MLNichols v. Pease, 207 U.S. 100 (1907); In re Waterman, supra note 12; Barnes v. Nelson, 23 S.D. 181, 121 N.W. 89 (1909); Higley v. Millspaw, supra note 12; People V. O’Brien, supra note 13; Ex parte Brewer, supra note 13.

15 Ex parte Royall, 117 U.S. 241 (1886); Ex parte Colier, 140 N.J.Eq. 469,55 A.2d 29 (1947), cert. den. 333 U.S. 829 (1948). In the Colier case, the court said that it was without jurisdiction to protect the petitioner's constitutional rights which were to be protected by the courts of the demanding state and the United States Supreme Court. This was in accord with the decision in Powell v. Meyer, 134 N.J.L. 169, 46 A.2d 671 (1946) aud was reiterated in Huff $\nabla$. Ayers, 6 N.J. Super. 380, 71 A.2d 392 (1950).

${ }^{10}$ Munsey v. Clough, supra note 13; Powell v. Meyer, 23 N.J. Misc. 222, 43 A.2d 175 (1945) ; Ex parte King, 139 Me. 203, 28 A.2d 562 (1942); State v. Gregg, 68 Ohio App. 397, 40 N.E.2d 167 (1941); In re Ryan, supra note 12; Cassis v. Fair, 126 W.Va. 557, 29 S.E.2d 245 (1944); Ex parte Colier, supra note 15; People v. Warden, 63 N.Y.S.2d 620 (1946).

${ }^{17}$ Pearce v. Texas, 155 U.S. 311 (1894); Hale v. Crawford, 65 F.2d 739 -(1st Cir. 1933).
} 
be questioned; $;^{18}$ and habeas corpus cannot be made to fulfill the functions of a writ of error. ${ }^{19}$

Similar considerations govern when the petitioner on habeas corpus challenges the executive warrant. The extradition papers, when regular on their face, are prima facie valid, and if the petitioner undertakes to controvert any fact essential to extradition, he must do so beyond a reasonable doubt. ${ }^{20}$ When it appears that the extradition papers were considered to be regular by the executive of the asylum state, the courts should not discharge the petitioner on technical grounds. ${ }^{21}$ Before the demand for extradition may be lawfully complied with by the governor of the asylum state, it must appear that the petitioner was "substantially charged" with a crime and was a fugitive from justice $;^{22}$ but whether the act charged is a crime or not is open to judicial inquiry. ${ }^{23}$ Whether the petitioner is a fugitive from justice is a question of fact for the governor of the asylum state, but his conclusion may be overthrown by contrary evidence presented to the court. ${ }^{24}$ The executive warrant when issued is regarded as making a prima facie case in favor of the demanding state, but it may be overthrown by evidence to the contrary, and the court may

${ }^{18}$ Higley v. Millspaw, supra note 12; Spiak v. Seay, 185 Va. 710, 40 S.E.2d 250 (1946); Tobin v. Commissioner, 89 N.Y.S.2d 15 (1949).

${ }_{10}$ LaRocque v. Enright, 115 Misc. 206, 189 N.Y.S. 167 (1921); Peoplo v. Hagerty, 262 App.Div. 45, 28 N.Y.S.2d 186 (1941).

20 Hale $\nabla$. Crawford, supra note 17; Hyatt $\nabla$. New York, supra note 12; Ex parte Paulson, 168 Ore. 457, 124 P.2d 297 (1942); Katz v. Superintendent, 162 Pa.Super. 459, 58 A.2d 366 (1948); Fx parte Ricardi, 68 Ariz. 180, 203 P.2d 627 (1949). The type of proceeding reforred to is ex parte in the state or federal courts of tbe asylum state.

2 Compton v. Alabama, 214 U.S. 1 (1909).

2 Hyatt $\mathrm{v}$. New York, supra note 12; Roberts $\mathrm{v}$. Reilly, supra noto 14; McNichols v. Pease, supra note 14; In re Ryan, supra note 12; Katz จ. Superintendent, supra note 20; Ex parte Paulson, supra noto 20.

${ }_{23}$ Hyatt v. New York, supra note 12; Ex parte Spears, supra note 12; In re Waterman, supra note 12; Powell $\nabla$. Meyer, 23 N.J.Misc. 222, 43 A.2d 175 (1945); Higley v. Millspaw, supra note 12; Sherman v. Barr, supra note 12.

24 Hyatt $\mathrm{\nabla}$. New York, supra note 12; Roberts $\mathrm{v}$. Rellly, supra noto 14; McNichols v. Pease, supra note 14. 
go behind the warrant to examine into the sufficiency of the papers on which it is based. ${ }^{25}$

In passing on habeas corpus petitions, there is a principle that good relations between the sisterhood of states require the prompt extradition to the demanding state of a fugitive therefrom. A number of courts have enunciated the dogma that to refuse extradition would lead to some sort of disruption of interstate harmony. ${ }^{26}$ In Johnson $v$. Matthews, ${ }^{27}$ the Court of Appeals said that the extradition provision of the Federal Constitution was in the nature of a treaty proviso between the states and that compliance was a matter of agreed executive comity, faithful obedience thereto being vital to the national welfare. The United States Supreme Court has stated ${ }^{28}$ that if more were required in an extradition proceeding than an inquiry into the technical sufficiency of the extradition, it would impose on the courts the duty of a critical examination of the law of states with whose jurisprudence they were only generally acquainted, and the burden would be intolerable, leading to irritation and conflict. Of course, this argument would cover only technical questions of law like the form of pleading, rather than questions of fact relating to denial of due process. As to the latter, it is argued that reprisals may occur if extradition is refused on the basis of unsupported testimony, and "many such refusals might result in the end of honor and comity between the states. . . The honor of each state requires the utmost fair dealing and reciprocity between

2 McNichols v. Pease, supra note 14; In re Waterman, supra note 12; Ex parte Shoemaker, supra note 13; Higley v. Millspaw, supra note 12; People v. Hagerty, supra note 19; Ex parte Paulson, supra note 20; Katz v. Superintendent, supra note 20; Powell v. Turner, 167 Kan. 524, 207 P.2d 492 (1949), cert. den. 338 U.S. 835 (1949); State V. Smith, 32 Ala.App. 651, 29 So.2d 438 (1947).

s Johnson v. Matthews, supra note 12; Ex parte Royall, supra note 15; Plerce v. Creecy, supra note 12; Appleyard v. Massachusetts, 203 U.S. 222 (1906) ; People v. Warden, supra note 16; Jackson v. Ruthazer, 196 Misc. 34, 90 N.Y.S.2d 205 (1949). Ex parte Blackstron, 220 P.2d $742(1950)$.

27 Supra note 12.

$\approx$ Pierce v. Creecy, supra note 12. 
them."29 A petitioner who invoked both the Federal Constitution and the United Nations Charter had his application denied by a court which relied heavily on such a "comity" argument. ${ }^{30}$

Yet some courts in effect say, "comity be hanged, we are going to do what is right here." ${ }^{31}$ And as one judge put it, "I would rather jeopardize the retention of the good will of anyone rather than to nullify, modify, or limit in any way the prerogatives of this great writ-the greatest bulwark of our liberty-and which gives every person under our glorious government the right to appeal to a judicial tribunal when restrained of his liberty."32 In Mattox $v$. Superintendent, ${ }^{33}$ the petitioner contended that if he were returned to Georgia he might face mob violence or at least hostile public reaction making justice difficult if not impossible of achievement. His discharge by the lower court was affirmed, the appellate court saying, "an ounce of pre-

m Jackson v. Ruthazer, supra note 27. Cf. Appleyard v. Massachusetts, supra note 27; People v. Warden, supra note 16.

so Ex parte Blackstron, supra note 27.

in In re Waterman, supra note 12; Mattox $\nabla$. Superintendent, 152 Pa.Super. 167, 31 A.2d 576 (1943); Johnson v. Dye, 175 F.2d 250 (3d Cir. 1949); Judge Bazelon dissenting in Johnson $\nabla$. Matthews, supra note 12. There is of course the argument that the court in the asylum state which hears the petition is not in an adequate position to decide the questions of fact raised by the petitioner's contentions. The argument presupposes a lack of evidence before the court. But it must be remembered that the petitioner is before the court, and a judge must, in the course of his professional career, have accumulated enough ingight into the character of witnesses so as to be fairly well capable of ascertaining the reliability of the witness and the weight which is to be given to his testimony. In Application of Middlebrooks, supra note 1 , the court remarked that it was impressed with the truth of petitioner's testimony and observance of him as a witness lent credence thereto. The authorities of the demanding state are in no wise precluded from appearing in the case. Of course, it ean be argued that this entails burdensome expense to the demanding state. The answer to this is obvious. It is a small price to pay for the protection of the rights of the petitioner. If the authorities of the demanding state are at all convinced of the justice of their claim and possessed of the evidence to sustain their rights in the matter, we may rest assured that they will obtain the wherewithal to present their case.

$\approx$ In re Waterman, supra note 12.

Supra note 31. 
vention in this respect is worth a pound of cure."34 In Johnson v. Dye, , $^{35}$ the court said that the petitioner "must be set at liberty for the State of Georgia has failed signally in its duties as one of the sovereign States of the United States to treat a convict with decency and humanity." And Judge Bazelon, dissenting in Johnson v. Matthews, ${ }^{36}$ thought that the court should be able to look into grave charges of cruel and inhuman punishment inflicted on the petitioner by the authorities of the demanding state.

If extradition were the only question involving the problem of interstate relations, something might be said for the view that the petitioner should be returned to the demanding state in the interest of something or other called "comity." A student of business studying state economic legislation would probably smile wryly if comity were mentioned, an outstanding example of the lack of comity in this field being the discriminatory tax placed on oleomargarine by states having a large dairy industry. The judicial dialecticians might do well to devote their efforts to fields other than extradition-that is if they are sincere in their assertions. ${ }^{37}$

\footnotetext{
${ }^{31}$ Georgia sent an attorney to participate in the proceedings. $\mathrm{He}$ charged the trial judge, Judge Fenerty, with having been biased and disqualified; because while a member of Congress, the judge had introduced an anti-lynching bill. The Superior Court said that this attitude was furtber evidence to support the decision below. Apparently in the opinion of the Georgia attorney, to be qualified to hear an extradition proceedings involving a southern state, the judge must be opposed to civil rights legislation or at least maintain a passive attitude tbereto.

as Supra note 31.

s3 Supra note 12.

37 An interesting comment regarding comity is found in Application of Midalebrooks, supra note 1. "A further result has grown up in the cases which is apparent to anyone making a study thereof; the rule of exhaustion of remedies in the State has been supplemented by the further rule tbat once the remedies have been exhausted ... then Federal courts are reluctant to intervene because of comity and out of respect for State courts. Thus there has been created an endless circle which if followed to its logical conclusion would deny to a Federal District Court the right to give relief for violations of basic constitutional rights ... the observance of these niceties and the concern concerning comity must give way on the assertion and the finding of the violation of basic constitutional rights."
} 
Irrespective of the willingness of state courts in the asylum state to rely on notions of "comity" and refuse to entertain petitions for habeas corpus, the federal courts in the asylum states have, in effect, been forced to decline jurisdiction by virtue of a series of recent Supreme Court decisions. These cases, developing the idea of "exhaustion of remedies" begin with $E x$ parte Hawk. ${ }^{38}$ The exhaustion of remedies principle is part and parcel of the larger concept of comity. It represents an attempt to achieve a comity of sorts between the state and federal judiciary.

The federal decisions of recent years regarding habeas corpus in general and extradition in particular are not harmonious. In Ex parte Hawk, the Supreme Court said that,
"ordinarily an application for habeas corpus by one detained under a state court judgment of con- viction for crime will be entertained by a federal court only after all state remedies available, in- cluding all appellate remedies in the state courts and in this court by appeal or writ of certiorari have been exhausted .... it is a principle con- trolling all habeas corpus petitions to the federal courts, that those courts will interfere with the administration of justice in state courts only in rare cases where exceptional circumstances of pe- culiar urgency are shown to exist."

Next in Wade v. Mayo, ${ }^{39}$ the Supreme Court held that certiorari or appeal from the state supreme court was not part of the state remedies to be exhausted before application for the writ could be entertained by the lower federal courts. It was pointed out that the reason for the rule of exhaustion of state remedies was to avoid conflict between the state and federal judiciary - a policy similar to that of "comity" between states. The reason for the rule was said to cease after the state procedure had been exhausted, and "there is no longer any danger of a collision between federal and state authority." The Court rejected the argu-

\footnotetext{
38 321 U.S. 114 (1944).

2334 U.S. 672 (1948).
} 
ment that the decision of the highest state court should be overturned by the Supreme Court, rather than a humble district court, saying that statistically there was little justification for the fear that a single federal judge would upset a denial of the writ by a state court.

Shortly after the Wade v. Mayo decision, 28 U.S.C.A. 2254 became law. ${ }^{40}$ It provided that an application for the writ of habeas corpus in behalf of one in custody under the judgment of a state court was not to be granted unless it appeared that the petitioner had exhausted the remedies available in the courts of the state, or unless there were no adequate state remedies available. The petitioner was not to be considered as having exhausted his state remedies "if he has the right under the law of the State to raise by any available procedure, the question presented." As both the House Report ${ }^{41}$ and subsequent federal decisions ${ }^{42}$ indicate, this new section was intended to codify $E x$ parte Hawk. But both the Senate Report ${ }^{43}$ and the section contain language indicating that the remedies to be exhausted are those "in the state courts." (Italics added.) And the Court of Appeals said in Miller v. Hudspeth" "an analysis of the Mayo case leads to the conclusion that certiorari is no part of state procedure for habeas corpus cases originating in state courts . . neither is there anything in 28 U.S.C.A. $\$ 2254$ which requires a contrary conclusion." The point was considered in Darr v. Burford, ${ }^{45}$ and the Supreme Court said, "It is immaterial whether as a matter of terminology it is said that review in this court of a state judgment declining relief from state restraint is a part of the state judicial process which must be exhausted, or whether it is said to be a part of federal procedure. The issue cannot be settled by the use of proper words." The Court, relying on

so Wade $\nabla$. Mayo antedated 28 U.S.C.A. \$2254 by approximately eleven days.

'1 Hse. REPT. 308, 80th Cong., 2nd Sess., p. A180 (1948).

4 See Darr v. Burford, 339 U.S. 200 (1950).

13 Sen. Rept. 1559, 80th Cong., 2nd Sess., pp. 9-10 (1948).

4 176 F.2d 111 (10th Cir. 1949).

¿Supra note 42. 
the statute, overruled Wade v. Mayo, and held that certiorari to the Supreme Court was part of the remedy involved in the "exhaustion of state remedies" rule, unless the petitioner showed circumstances of peculiar urgency requiring prompt federal intervention. . $^{48}$

It did not appear whether the Court intended these decisions to apply to habeas corpus in extradition proceedings and if so whether the remedies in the courts of the asylum or the demanding state or both were to be exhausted before an application for the writ would be entertained by the federal courts.

Prior to Darr v. Burford, several cases involving the extradition problem were decided by the federal courts. The first case was Johnson v. Dye. ${ }^{47}$ The petitioner, an escapee from a Georgia chain gang, had been denied a discharge by the lower Pennsylvania court, ${ }^{48}$ on the ground that there was sufficient evidence to justify his conviction. The state court made little or no inquiry into Georgia prison conditions. The petitioner then turned to the federal district court which, while admitting that there was evidence that he had received cruel and inhuman treatment at the hands of the Georgia authorities, said the Eighth Amendment was not a limitation on state action and refused to order his discharge. ${ }^{49}$ The Court of Appeals granted the application for the writ and ordered the petitioner discharged. ${ }^{50}$ The petitioner had not exhausted the remedies of the asylum state, but the Court held that the doctrine of exhaustion of state remedies did not apply to extradition proceedings. The Court then said that cruel and inhuman punishment was violative of the due process clause of the Fourteenth Amendment, that the right to be free from such punishment was

\footnotetext{
16 Inasmuch as the Senate REPort did not contain the reference to Ex parte Hawk appearing in the HOUSE REPORT, the latter should not be given exclusive weight as the expression of the will of Congress. If Congress intended to codify Ex parte Hawk, language more apt for that purpose should have been included in 28 U.S.C.A. $\& 2254$.

17175 F.2d 240 (3d Cir. 1949), rev'd 338 U.S. 864 (1949).

4159 Pa. Super. 542, 49 A.2d 195 (1946).

4971 F.Supp. 262 (W.D. Penn. 1947).

so Supra note 47.
} 
a basic and fundamental right, and that, therefore, the provisions of the Eighth Amendment were made applicable to the states through the due process clause of the Fourteenth Amendment. 51

In a terse per curiam opinion, the Supreme Court granted certiorari and reversed the judgment on the authority of Ex parte Hawk. ${ }^{52}$ Apparently, the decision overruled the attempt to create an exception in the extradition cases to the doctrine of exhaustion of state remedies. But did the Court mean that the remedies available in Georgia, the demanding state, or those available in Pennsylvania, or both were to be exhausted; or that appeal and certiorari to the Court was a part of the exhaustion of state remedies required before federal relief could be granted?

Another escapee from Georgia was involved in the next case, $E x$ parte Marshall. ${ }^{33}$ The petitioner alleged general brutal treatment under the Georgia penal system and that particular cruelties and indignities had been inflicted on him, but Georgia authorities testified to great humanitarian changes made in the state's penal system in recent years. ${ }^{54}$ The Court approved of the decision in Johnson $v$. Dye, but distinguished the case before it on the ground that there had been no threatened reprisal to the petitioner on his return to Georgia; his allegations of cruel and inhuman treat-

81 Again, it is to be noted that the Court said that the petitioner "must be set at liberty for the state of Georgia has failed signally in its duties as one of the sovereign states of the United States to treat a convict with decency and humanity." The Court took notice of prison conditions not only through the petitioner's testimony but through articles in Trare and LIFE magazines and the REPOBT of THE PREsment's CoMrMities on Crvil RIGBTs. It may be questioned whether such sources are acceptable evidence. However, the two weekly news magazines have achieved a high degree of reputability in the field of news reporting. The eminent character of the persons comprising the President's Committee on Civil Rights must, concededly, lend authenticity to its REPORT.

supra note 47.

65 F.Supp. 771 (D. N.J. 1949).

5t The officials of the demanding state did not appear in the Dye case to controvert the allegations of the petitioner, and the court there felt that, under the circumstances, the evidence was of sufficient weight to justify the discharge. 
ment were not sustained by the evidence, and while particular acts of cruelty were admitted, the Court felt that to free the petitioner for that reason would be to set at large every criminal who, having been mistreated by an employee of the penal institutions of one state later escaped to another state.

A similar problem was involved in Harper $v$. Wall ${ }^{55}$ where the petitioner when fifteen years old to extract a confession had been beaten and had been denied counsel. He escaped to New Jersey where the local county court, in effect, directed him to apply to the Federal District Court for discharge on a writ of habeas corpus. This was done and that Court ordered him discharged from custody. The Court relied on the Court of Appeal's opinion in Johnson v. Dye for the doctrine that the rule of exhaustion of state remedies did not apply to extradition proceedings. Denial of counsel to an unversed youth of fifteen made the initial trial in Alabama unfair and, in conjunction with the cruel and inhuman punishment meted out to the petitioner constituted a violation of the Fourteenth Amendment.

Both Ex parte Marshall and Harper v. Wall were decided before the Supreme Court reversal of Johnson v. Dye. That the confusion in the federal courts was not resolved by the latter case is demonstrated by Johnson $v$. Matthews ${ }^{56}$ which involved another Georgia fugitive who made the usual allegation of cruel and inhuman treatment during his Georgia confinement. The Court of Appeals divided. The majority apparently felt that even though everything the petitioner said was true, it was of no moment. They said that the state courts of the asylum state and the federal courts having jurisdiction therein "cannot" hear and determine the constitutional validity of the penal action of the demanding state. In taking this bold position, the fact was apparently ignored that what the court said cannot be done had been done innumerable times in the past-and

שs 85 F.Supp. 783 (D. N.J. 1949).

to 182 F.2d 677 (D.C. Cir. 1950), cert. den. 340 U.S. (adv. sht.) 828 (1950). Much of the conflict in the decision was contained in two footnotes, one in the majority and the other in the dissenting opinion. 
undoubtedly will be done in the future. Judge Bazelon, dissenting, would have classified within the group of rights standing in a preferred position under the Constitution, the right of the individual to be free from cruel and inhuman punishment. And he felt there was danger that the extradition process was becoming too mechanical and completely disregarding the fundamental considerations of humanity and decency reflected in the Bill of Rights.

The majority viewed the reversal in Johnson v. Dye as meaning that a petitioner in an extradition proceeding must have first exhausted his remedies in the courts of the demanding state before he could be granted federal relief. They said that to interpret the reversal as holding that the petitioner had only to exhaust the remedies of the courts of the asylum state would mean that those courts had the jurisdiction to grant the petition on the grounds alleged, cruel and inhuman treatment, and that would "have been a revolutionary reversal of all the cases ever written on the subject." Judge Bazelon viewed the Johnson v. Dye reversal as merely holding that all of the remedies in the state of detention were to be exhausted before application for relief was made to the federal courts, for the petitioner there had not applied to the highest court of the asylum state. Bazelon pointed out that Ex parte Hawk did not involve the question of remedies in a foreign jurisdiction. To read what the majority read into a per curiam reversal, clearly procedural in origin, was, he said, to depart from the plain meaning of the Supreme Court. He thought the reference to Ex parte Hawk was to reject the attempt of the lower court in Johnson v. Dye to carve out an exception to the rule of exhaustion of state remedies in extradition proceedings.

Apparently then the view of the majority in Johnson $v$. Matthews is that there is, from a practical standpoint, no longer any federal remedy available by habeas corpus in an extradition proceeding as they would confine granting the writ to cases where the petitioner had previously exhausted the remedies of the courts of the demanding statepresumably including a petition for certiorari. It is doubt- 
ful if any petitioner would have exhausted those remedies. Thus he would not, in their opinion, be eligible for a discharge on habeas corpus in a federal court while he was outside the territorial jurisdiction of the courts of the demanding state. This is, indeed, a strong doctrine to derive from the short per curiam reversal in Johnson v. Dye, and it is predicted that the Supreme Court will not accept this exegesis of that case. ${ }^{57}$

The extradition proceeding poses grave moral and legal questions for the judge hearing the petition for the writ, especially if the demanding state is southern and the petitioner is a Negro. The abuses in the judicial and penal systems of some of the southern states as well as the inability of the citizenry in some localities to adapt their passions to conform with the criminal trial procedure of a democratic society have often been commented on..$^{58}$

The judge in an extradition proceeding must decide whether he will mechanically apply the strict letter of the

57 See Application of Middlebrooks, supra note 1. The court there explicitly stated that the petitioner need not exhaust his remedies in the demanding state, and while it was arguable that he might receive rellef there, "as a practical matter it is extremely remote that any relief would be granted him." The court said that the contrary argument was "unrealistic reasoning. . The argument is fallacious ... if constitutional rights and basic liberties are to be protected, they must be protected in the courts where the questions arise, and the shunting of a case from one court to another should so far as possible be avoided." In Jackson v. Rutbazer, 181 F.2d 588 (2nd Cir. 1950), cert. den. 339 U.S. 980 (1950), the Court of Appeals clearly inferred that the exhaustion of state remedies contemplated in extradition proceedings were those of the asylum state.

ss The attempted lynching on May 22, 1947 of Godwin Bush, Negro, in Jackson, North Carolina. REPOBT of THE Presment's CoMrMItTeE oN CIVIL RIGETs, 23. The murder of four Negroes by a band of whites on July 20, 1946 near Monroe, Georgia, REPORT, 22. The acquittal of the lynchers of Willie Earl, Negro in Greenville, South Carolina on May 21, 1947. REPOET, 23. The police brutality is equally shocking. The warden, "I got a right to knock them in the head and drag 'em to the hot box [a small metal box out in the open in which the temperature gets quite high on a sunny day]." Tnse, June 13, 1949, p. 23. The killing and wounding of seventeen Negro prisoners at Anguila state prison near Brunswich, Georgia. New RepuntIc, July 28, 1947, p. 11. "The incidence of policy brutality against Negroes is disturbingly high." REPORT, 27. The list could go on. The doubter is referred to any periodical index. 
constitutional clause and the applicable local extradition law or whether he will give more than lip service to the intent and purpose of the constitutional and statutory provisions. If he does the latter, he incurs the possibility of having impeachment proceedings instituted against him. ${ }^{\mathbf{5 9}}$ But, "Neither the Uniform Extradition Act . . . Nor Article IV, $\S 2$, cl. 2 of the Constitution of the United States, Nor the Acts of Congress, Regulating Interstate Extradition, Prevail over the Fourteenth Amendment."60

The question arises as to whether habeas corpus in extradition proceedings is a suitable tool for preventing abuses in another state or whether other procedures might be better. This raises the further question of what other procedures are available. Action by citizens in such states to correct penal, trial and other abuses seems only a distant

to Federal District Judge James A. Lowell, who had discharged the petitioner in Hale v. Crawford, supra note 17, said that if the discharge were not granted, the case would go to the Supreme Court on constitutional grounds. "This whole thing is absolutely wrong. It goes against my Yankee common sense to have a case go on trial for two or three years and then have the whole thing thrown out by the Supreme Court. Why should I send a negro back from Boston to Virginia when I know, and everybody knows, that the Supreme Court will say that the trial is illegal. I'd rather be wrong on my law than give my sanction to legal nonsense." N. Y. Trues, April 25, 1933, §1, p. 32, col. 2. The judge further said that Virginia had not upheld the laws of the United States when it came to putting Negroes on juries, and to him, the whole thing was a piece of stage play. Virginia was quick to reply. Congressman Smith introduced H.Res. 120 to inquire into the possibility of impeaching the judge. Smith charged Lowell with use of his judicial position for "the unlawful purpose of casting aspersions and attempting to bring disrepute upon the administration of justice in tbe Commonwealth of Virginia." 77 CoNG. REc. pt. 3, p. 2415 ff. During his utterances ou the virginity of Virginia justice, Smith said that there was no race question in Virginia. He was right, at least as to the jury which eventually found Crawford guilty, for it was composed entirely of whites. But no appeal was taken, for counsel had said tbat the defense would be satisfled with a life sentence. That was what Crawford received. It is interesting to note that the Boston Bar came to the defense of Judge Lowell. N. Y. Trares, April 30, 1933, 1 , p. 33 , cols. $4-5$. It might be contended that the result here indicates that the extradition of the petitioner did not result in the perversion of justice. The contention is tenable only if it is assumed that the systematic exclusion of Negroes from trial juries is in accord with the acbievement of a just decision. Such is hardly the case.

Application of Middlebrooks, supra note 1. 
hope, for these citizens either condone the abuses or acquiesce therein; and should prosecution of the guilty parties be pressed, it would be difficult or impossible to secure a conviction. ${ }^{61}$ There is little probability of state officials taking affirmative action in the foreseeable future, ${ }^{62}$ The federal government is rendered sterile by the filibuster in the Senate and the Rules Committee in the House.

Of course, refusal to honor the request for extradition is a poor tool for the correction of abuses. It reaches not the root of the trouble, but only a particular manifestation thereof. The petitioner may be guilty of grave crimes and to refuse to extradite him might only put a premium on the successful escape. But, admitting all that, it is not consonant with the spirit of the Bill of Rights and government in a democratic society to return a prisoner, however reprehensible his crime, to a jurisdiction where it is possible that he may not receive a fair trial, and after conviction may have visited upon him punishment of a cruel and inhuman nature. ${ }^{63}$

The question of whether the policies of the asylum state should be imposed on the demanding state, while adroitly put, is of little consequence once its full import is understood. The supposition is that some sort of "foreign ideology" would be imposed on the demanding state. This is not true. Assuming the policy of the asylum state to be against cruel and inhuman treatment of prisoners and for the decorous and decent conduct of judicial proceedings and the safeguarding of the person of the prisoner both pending and after the completion of such proceedings, it is difficult, indeed, to see how anything of an obnoxious nature is being imposed on the demanding state. It would seem that the question properly should be, "should the policies of the demanding state be imposed on the rest of the nation?"

\footnotetext{
a RePort, 20-29.

22 This is especially true of the present administration in Georgia under Talmadge II.

* The possibility becomes a probability if the petitioner is a Negro charged with a crime of violence against a white.
} 
This is the true aspect of the problem. The entire country, not an isolated segment thereof, suffers wherever and whenever an abuse occurs. The communist propagandists seize on such incidents and seek to convince peoples of other races and colors that there are two standards of justice in the United States, one for the dominant white group, and another for minority groups. ${ }^{64}$ This redounds to the benefit of the opponents of democracy and as a necessary result adversely affects the welfare of the entire nation. The problem is not to be viewed solely through the eyes of the demanding state.

In conclusion, it may be said that in the extradition cases the courts have certain formalisms which they announce as settled doctrine. The most obvious, of course, is the "comity" fiction. It is probable that the courts keep this arsenal of verbalisms on tap so that they may have an extra peg on which to "hang" a decision should the need arise. But most courts confronted with a petitioner who could substantiate his contention of particular abuses with convincing evidence would probably feel compelled to grant a discharge. The interest in maintaining minimum standards of justice would outweigh other considerations.

In the light of Johnson v. Matthews the situation in the federal courts is not clear. It is doubtful that, when a proper case is presented, the Supreme Court will adopt the extreme view taken by the majority of the Court of Appeals in that case. The Supreme Court will probably, for a time at least, adhere to the decision in Darr v. Burford that exhaustion of state remedies includes certiorari or appeal to the Court. As to extradition cases, the Court will likely adopt the view of Judge Bazelon, dissenting, in Johnson v. Matthews that the remedies to be exhausted are those of the asylum state.

The problem is complex and does not admit of an easy solution. It is closely allied with the more general question of Civil Rights. The cases posing the serious questions are those involving Negroes facing extradition to a southern

as In Application of Middlebrooks, supra note 2, the court took notice of the use for political purposes by "disloyal groups" of instances of cruel and inhuman treatment of prisoners. 
state. If there were no race problem, it is doubtful that there would be much of an extradition problem, but until the former is solved, the latter will remain.

A possible answer to the problem could be worked out by the judiciary, state or federal, in the asylum state committing the petitioner to the custody of the demanding state on the condition that he be accorded a fair trial and treatment. The condition could be enforced by requiring the demanding state to post a bond large enough to ensure its compliance with the terms of the extradition. But in any event, "Courts, and particularly Federal courts should be ever ready to listen with a sympathetic and tolerant ear to persons who claim their constitutional rights have been abridged. The untreated wound becomes an ulcer and the ignored grievance a cause." $" 65$

${ }^{\infty}$ Application of Middlebrooks, supra note 1. 